\title{
Advanced Turbine Systems Program Conceptual Design and Product Development
}

\author{
Quarterly Report \\ February - April 1996
}

Work Performed Under Contract No.: DE-AC21-93MC30247

For

U.S. Department of Energy

Office of Fossil Energy

Morgantown Energy Technology Center

P.O. Box 880

Morgantown, West Virginia 26507-0880

By

Westinghouse Electric Corporation

Emerging Technologies

Power Generation Business Unit

4400 Alafaya Trail, MC381

Orlando, Florida 32826-239 


\section{Disclaimer}

This report was prepared as an account of work sponsored by an agency of the United States Government. Neither the United States Government nor any agency thereof, nor any of their employees, makes any warranty, express or implied, or assumes any legal liability or responsibility for the accuracy, completeness, or usefulness of any information, apparatus, product, or process disclosed, or represents that its use would not infringe privately owned rights. Reference herein to any specific commercial product, process, or service by trade name, trademark, manufacturer, or otherwise does not necessarily constitute or imply its endorsement, recommendation, or favoring by the United States Government or any agency thereof. The views and opinions of authors expressed herein do not necessarily state or reflect those of the United States Government or any agency thereof. 


\section{DISCLAMMER}

Portions of this document may be illegible in electronic image products. Images are produced from the best available original document. 


\title{
QUARTERLY STATUS REPORT
}

\author{
Date: $\quad$ July 8, 1996 \\ Report No. TPR-11 \\ Reporting Period: February, 1996-April, 1996
}

CONTRACT TITLE AND NUMBER: Advanced Turbine Systems Program --

Conceptual Design and Product

Development DE-AC21-93MC30247

CONTRACTOR'S NAME:

Westinghouse Electric Corporation

Power Generation Business Unit

4400 Alafaya Trail

Orlando, FL 32826-2399

CONTRACT PERIOD:

August 5, 1993 to July 5, 1996

\subsection{SELECTION OF NATURAL GAS-FIRED ADVANCED TURBINE SYSTEMS (GFATS)}

Task completed.

\subsection{SELECTION OF COAL-FIRED ADVANCED TURBINE SYSTEMS (CFATS)}

Task completed.

\subsection{MARKET STUDY}

The market study was completed. The study results were submitted in draft form as Topical Report Task 5.0 on January 30, 1996. The revised final report was submitted on March 19, 1996.

\subsection{SYSTEM DEFINITION AND ANALYSIS}

This task was completed. Study results was submitted in draft form on February 13, 1996. 


\subsection{DESIGN AND TEST OF CRITICAL COMPONENTS}

\section{$\underline{\text { Last Row Turbine Blade Development }}$}

In prior developments the BVM was tested using a two probe approach. Subsequent developments resulted in a 16 probe system suitable for monitoring synchronous and nonsynchronous vibration during various engine operating conditions. Initial stage 4 vibration tests showed low amplitude responses. Additional testing was completed with no significant levels of vibration being reported. A summary report of the testing has been released. A final report is scheduled for completion before June 30, 1996. Casting trials for Row 4 blades were successfully completed in April.

\section{$\underline{\text { Single Crystal Blade Casting Development }}$}

This task has been completed. Subsequent work has continued into Phase 3.

\section{Ceramic Materials Development}

Generation of the material database for the Nicalon Alumina ceramic matrix composite (CMC) continued at ORNL under the User Program. Tests have also been started at University of Dayton Research Institute. During March two studies - the cost/benefit analysis of ceramic ring segment and the risk assessment associated with the development of CMC ring segment were concluded. Metallographic and mechanical characterization of the abradable layer friable graded insulation(FGI) for the $\mathrm{CMC}$ ring segment continued at Westinghouse STC. Also, a higher temperature version of the FGI is being developed which will improve the thermal protection of the CMC under ATS conditions. A plan to test critical building blocks and features (subelements) of the CMC ring segment has been prepared and quotation obtained for their manufacture.

\section{Combustion Cylinder Flow Mapping}

This task has been completed. All experimental work has have been completed. The topical report and several technical papers are in the process of being written.

\section{Shroud \& Airfoil Film Cooling}

Testing of all initial non-film cooling configurations is complete. All shroud film holes are in place for the initial array tests. Film testing about to proceed.

\section{$\underline{\text { Directionally Solidified Blade Development }}$}

Tensile and LCF tests for CC CM247 material have been completed. HCF and creep test specimens of DS CM247 are being coated for evaluating coating effects. For the evaluation of 
withdrawal rate effect, test slabs of DS M002 and DS CM247 were heat treated, and machined in preparation for mechanical testing. Tensile and fatigue tests for $\mathrm{CC}$ blade evaluation have been completed, creep tests are in progress. Testing of 6 " per hour withdrawal rate is in progress. For evaluating $\mathrm{CC}$ blades, the tensile and fatigue tests have been completed, and creep testing is in progress. DS CM 247 blades have been NDE inspected. The blades are being machined for mechanical property evaluation. DS M002 blades have been inspected by casting supplier, and will be shipped in next month.

\section{Shrouded Blade Cooling}

Task completed.

\section{Closed-Loop Steam Cooling}

The conceptual design for row l vane and blades has been completed. Detailed design of row 1 vane and blades will continue into Phase 3.

\section{Active Tip Clearance Control}

The ceramic abradable coating development work has been completed.

\section{$\underline{\text { Flow Visualization Tests }}$}

This task was completed.

\section{Combustion Noise Investigation}

Currently, a series of open loop tests are being run at STC using a small scale combustor which replicates key aspects of the (W) Piloted Ring design. Testing earlier in the month at STC had shown the combustor provided sharp instability peaks as designed and intended. In recent days, the Georgia Tech electronically controlled fuel modulator was installed and testing was begun at lower pressures and flow rates (about 50 psia). The test program plan includes both open loop and closed loop tests during the current series. 


\section{$\underline{\text { TBC Field Testing }}$}

Field testing on 501D5 ring segments has been in progress since March 1995, accumulating over 8000 hours of operation. First inspection, after about 7000 hours of operation, was made on March $18-19,1996$. Only visual observation of ring segments through gaps between row 1 vanes was possible. Photo documentation was made of ring segments that were visible to the naked eye. No surface discoloration or minor discoloration was observed without any scoring in almost all segments, except a ring segment that had MCrAlY + EB-PVD TBC. Chipping of about $1.00 \mathrm{X} 0.5$ inch in area was observed near a mating face (edge) of this ring segment which had MCrAlY + EB-PVD TBC.

\section{Catalytic Combustion Development}

One phase of the flow visualization test on the EGR combustor was completed at the Casselberry test facility. The required flow area for $10 \%$ exhaust gas recirculation was established.

Alterations in the main swirl plate were made to lower the pressure drop in the EGR configuration while still maintaining adequate flame holding recirculation flow. An SLA version of a ring configuration was designed, built and tested in the Casselberry cold flow rig. During the past month, we received the catalytically coated monolith from Engelhard for testing at the STC small scale combustion lab. This is a metallic substrate honeycomb device which will be used in emission characterization and durability experiments in support of our EGR catalytic combustor initiative. The catalytic combustion apparatus is being reassembled into the STC test rig with a modified fuel injection configuration from previous runs and it is expected that the testing will begin in June.

\section{Optical Diagnostics Probe Development}

During the past month, a report was written by Penn State on the results of our January full scale test with the Piloted Ring combustor. We are now planning for a test with the K-Point combustor to be run at the atmospheric pressure test facility at Casselberry.

\section{Serpentine Channel Cooling Tests}

All thermal testing was completed. Pressure loss testing on the tracking edge model was completed. Data analysis is in progress.

\section{$\underline{\text { Brush Seal Development }}$}

Brush seal development work with EG\&G (Warwick, RI) for the turbine interstage location was completed. Wear testing was completed of two sub-scale seals on their "aerospace" rig. Seal no. 1 , a generic brush seal, and Seal no. 2 , a brush seal with proprietary features, were each tested 
for over 500 engine start-up simulation cycles until wear ceased. EG\&G has submitted a draft of the task report. The report will be published after review and approval by Westinghouse. The results from this task will be used in Task 9.6 to design full-scale turbine interstage seals for the $501 \mathrm{G}$ and ATS engines. In March, 1996, the brush seal development effort at EG\&G (Warwick, $\mathrm{RI})$ was completed. The results of this subtask will be used in Subtasks 8.29 and 9.6 to design and fabricate full-scale turbine interstage seals for the $501 \mathrm{G}$ and ATS engines.

\section{High Efficiency Compressor Design}

The S1-S2 methodology calibrated against the $501 \mathrm{~F}$ is being applied directly to the high efficiency compressor blading, and results to date show that the design is performing as expected. Hot and cold weather analyses are gradually converging, with no stoppers thus far. Starting bleed systems analysis procedure definition continues with benchmarking against both $501 \mathrm{D} 5$ and $501 \mathrm{~F}$ data. Hot radial clearances are being predicted.

Design reports are being written for all airfoils. Blade dovetail design and analysis has been completed for all rows.

\section{$\underline{\text { Advanced Air Sealing Development }}$}

EG\&G has continued development of brush seals for the compressor diaphragm location and a feasibility study for applying brush seals at the turbine rim. Further, effort continued in full-scale design of brush seals for the turbine interstage location based on results from Subtasks 8.23 and 8.24. Hardware fabrication is nearly complete for tribology testing for both the compressor diaphragm and turbine rim. Hardware fabrication for compressor diaphragm subscale rig testing is in progress.

\section{Advanced Coating Development}

Long-term testing of bond coats at $1850 \mathrm{~F}$ is continuing with exposure times out to 7000 hours. The Westinghouse baseline coating system deposited on IN-939 has failed. Additional more promising bond coat systems remain in test.

Test pins with new ceramics were delivered. Two new ceramic TBC compositions have been formulated and powders are being fabricated.

Ceramic compositions have also been formulated as alternatives to $8 \%$ YSZ. Specimens are currently being fabricated for two compositions. Powders for two additional compositions are being fabricated. 


\section{$\underline{\text { Single Crystal Blade Development }}$}

The aging heat treatment of CMSX-4 specimens, which included a matrix of 16 time-andtemperature combinations, has been completed. The specimens have been prepared for metallographic evaluation, and the analysis of morphology in various aged conditions is in progress. This analysis will be completed next month. The differential thermal analysis (DTA) results have been reviewed with Cannon Muskegon. These results regarding solidus and liquidus temperatures were in agreement with Cannon Muskegon's data. However, using DTA to identify incipient melting was found to be inadequate because of signal-to-noise-ratio issue. Since incipient melting was not observed in any on the specimens, the DTA evaluation will not be further pursued.

\section{Ni-Based Disc Forging Development}

Forging from Wyman Gordon has been completed. Specimen machining of Alcoa material is in progress. Creep test have proceeded, some data has been collected.

\section{$\underline{\text { Steam Cooling Effects on Materials }}$}

Solubility and stability of compounds have been evaluated. Review of melting point and eutectic data is in progress. Subcontractors to develop the deposition model are being interviewed.

\section{PLANS FOR THE NEXT REPORTING PERIOD}

Task

6.0 Issue final topical report, ATS engine and plant conceptual designs

8.3/8.13/8.26 Issue a report on BVM field test results

8.7/8.32 Complete report on abradable layer characterization

Accumulate hours on stress rupture tests

8.8 Complete topical report

8.10 Complete model tests at Dynalysis

8.11 Continue material property tests

8.14/8.31 Task completed

8.17/8.35 Continue active noise control concept verification testing 
8.18 Monitor performance of TBC blades already installed on 501D5

8.19 Continue testing of catalytic combustor with modified fuel injection

8.20 Continue probe evaluation test at atmospheric pressure and high temperature

8.22 Continue data reduction

8.23/8.24 Review task report

8.25/8.27 Complete design reports for all airfoils

8.29 Continue rim and compressor diaphragm seal development.

8.30 Continue development of advanced bond coat/TBC system.

8.32 Continue ceramic material development

Complete economic assessment

8.33 Complete metallographic evaluation and morphology analysis

8.37 Continue data analysis of first disc material, receive and test second disc

8.38 Select subcontractor for deposition model development

This concludes a summary of the activities for the months of February, March and April 1996. Submission of this report constitutes completion of the reporting requirement for the quarterly report for the stated period.

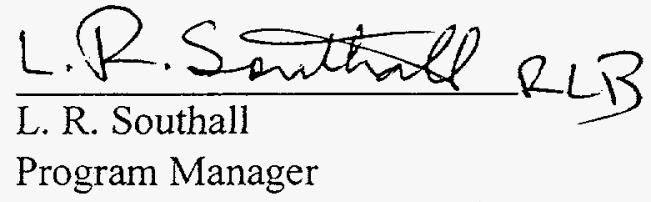

Attachments:

List of Acronyms and Abbreviations 